RJOAS, 9(105), September 2020

DOI https://doi.org/10.18551/rjoas.2020-09.09

\title{
PARTNERSHIP STRATEGY ON THE BUSINESS PERFORMANCE OF AUTOMOTIVE LUBRICANT COMPANIES IN INDONESIA
}

\author{
Dina Nur* \\ UniSadhuGuna Business School, Indonesia \\ Yulivan Ivan \\ Indonesia Defense University, Indonesia \\ Zultaqawa Zeis \\ Department of Business Administration, University of Padjadjaran, Indonesia \\ *E-mail: nurdinapaper@gmail.com \\ ORCID: 0000-0003-2424-722X
}

\begin{abstract}
The purpose of this study is to examine the effect of the business environment and company assets on the partnership strategy and its implications for the business performance of automotive lubricant companies in Indonesia. The research method is carried out using an explanatory survey approach. The unit of analysis is an automotive lubricant company in Indonesia, where the observation unit is the management of the lubricant company. Observations were carried out using the cross-section and one-shot time horizon in 2020. Questionnaires were collected through a census conducted on 32 national automotive lubricant companies in Indonesia. Hypothesis testing is done using the Structural Equation Model (SEM) with partial least squares (PLS). This research was conducted to encourage the management of automotive lubricant companies in Indonesia to improve business performance, that it needs efforts through the development of an appropriate partnership strategy, built with business environment adaptations, especially in macro-environmental aspects and supported by the ability to develop company assets, especially intangible assets. The results of the study indicate that the partnering philosophy has the highest influence on business performance. Based on the results of these tests, the automotive lubricant industry business performance is more predominantly built by a partnership strategy, and to build an appropriate partnership strategy, it is necessary to encourage the company's ability to adapt to a business environment supported by the ability to develop company assets.
\end{abstract}

\section{KEY WORDS}

Business environment, company asset, partnership strategy, business performance, lubricant companies.

The growth in the number of motorized vehicles, both motorbikes, and cars, has caused market demand for automotive lubricants to also tend to increase significantly. The need for automotive lubricants is greater than industrial lubricants so that they have a greater opportunity. The number of factories or automotive lubricant manufacturers exceeds the number of industrial lubricant factories. This shows that automotive lubricants are in a more hypercompetition position than industrial lubricants, so they are more interesting to study.

Until now, Pertamina is still able to be the market leader in the automotive lubricant industry, while its followers are only able to control the market far below $20 \%$. Therefore, these conditions indicate that the automotive lubricants business performance is not yet optimal. Meanwhile, based on observations, problems were found related to company assets. The 
production facility is partly old. Besides, there are also problems with financial resources. Part of the reputation of lubricant products is still low when compared to imported products.

Meanwhile, based on observations, problems were found related to company assets. The production facility is partly old. Also, there are problems with financial resources. Part of the reputation of lubricant products is still low when compared to imported products. Some literature mention market share as an indicator of business performance, such as (K. Griffin, 2003;2011; 2006; Hunger \& Thomas. L. Wheelen, 2004; 2012;2010; Teece, 2010).

Empirically, previous research shows that business performance is related to the partnership strategy. (Makau et al., 2017) found that the buyer-supplier relationship can increase competitive prices, reduce lead time, reduce non-supply risk, improve delivery reliability, improve inventory management, increase sales, and improve customer satisfaction. Besides, (Song et al., 2012) found that the business partnership function has a direct and indirect effect on buyer performance through the mediating effect of the quality of the relationship. Meanwhile, observations indicate that no strategic alliance has been created among lubricant companies. Meanwhile, according to (Hoskisson et al., 1999; 2000), collaboration with other companies is a strategy to create value for customers that cannot be created by the company alone (Hitt et al., 2012).

The partnership strategy is closely related to company assets and the business environment (Liao et al., 2011) argues that the relationship between human resource capabilities, internal customer satisfaction and commitment, and organizational effectiveness (Chuang et al., 2015). Previously (Wu \& Lu, 2012) found that the ability of suppliers and partnerships is significantly positively correlated, and both positively affect competitive advantage.

Other studies also show a relationship between the partnership strategy and the business environment, (Hibbets et al., 2003) mentioning the relationship between the competitive environment faced by the company and the company's strategy. Besides, research results (Essmui et al., 2014) show a strong relationship between sales growth and factors such as corruption, crime, finance, infrastructure, business regulations, and human resources. This illustrates that the business environment has an impact on business performance (Hodud Essmui et al., 2014). Meanwhile, based on the results of observations made by researchers, it was found that companies were not yet fully able to anticipate the movement of competitive conditions, both in the short and long term. Lubricant companies are also still not able to fully anticipate the shift in customer demands which makes it difficult for the product to be absorbed by the market.

\section{LITERATURE REVIEW}

The business environment indicates external and internal forces and institutions outside the control of individuals within the company that can influence both directly and indirectly on the company's business (Porter, 1980). (John A Pearce \& Richard B Robinson, 1988) argues that the main aspect of strategic management is the need to formulate various strategies to take advantage of external opportunities and minimize the impact of external threats. The external environment is divided into the external environment (remote environment), industrial environment (industry environment), and operational environment (operating environment). (Teece, 2012) states that external forces are divided into five broad categories, namely: (1) economic strength, (2) social, cultural, demographic, and environmental forces, (3) political power, governance, and law, (4) technological strength, (5) competitive power.

The business environment includes aspects of legal status, taxation, competition, and the presence of foreign markets (Pearce \& Robinson, 2011). Based on this conceptual study, the business environment variables in this study are measured based on the dimensions of the macro and microenvironment. (Ch et al., 2011) divides the external environment into a macro 
environment and a microenvironment. The macro-environment includes political, economic, social, and technological aspects. Meanwhile, the microenvironment is a company stakeholder who has control over the company such as suppliers, customers, retailers, and competitors. Meanwhile, in the opinion (Afsharghasemi et al., 2013) the business environment includes economic, political, cultural, technological, and demographic aspects.

A resource according to (D. W. Cravens et al., 2009) is a complex set of aspects consisting of organizational processes, accumulated knowledge and expertise, coordinated activities, and asset utilization. According to (Pearce \& Robinson, 2011), resources consist of tangible assets, intangible assets, and organizational capabilities. In general, (Hoskisson et al., 1999) divides resources into tangible resources, intangible resources, and capabilities. Tangible resources are resources that can be observed and calculated, such as production equipment, manufacturing facilities, distribution centers, and formal reporting structures. Intangible resources are resources hidden in the history of the company, which are the accumulation of experience, and are relatively difficult for competitors to analyze and imitate. Based on the study of the concept, the company asset in this study is measured by dimensions consisting of tangible assets and intangible assets.

(Todeva \& Knoke, 2005) revealed that companies that compete in today's business environment form strategic alliances for various strategic goals (Sambasivan et al., 2009). Through active involvement in strategic alliances, several positive results, from resource acquisition to synergy creation, can be obtained with several alliance partners (Sambasivan et al., 2013). (Uddin \& Akhter, 2011) stated that strategic alliances are designed to respond to competition and to reduce uncertainty and to create competitive advantages.

Early research on the concept of a partnership strategy was carried out in 1990, which was pioneered by (Porter, 1985) which defines the concept of a partnership strategy as a form of a long-term agreement between companies and partners in achieving common goals, this form of cooperation includes such as joint ventures, licensing, long-term agreements, and relationships between other companies (Porter, 2008).

The partnership strategy is a comprehensive and systematic collaboration, to clarify goals, make decisions, and check progress in achieving goals (Agboola \& Braimoh, 2009). According to (Jackson \& Wolinsky, 1996) the partnership strategy is an effort to collaborate with stakeholders, where the partnership strategy is currently used by many companies in competition around the world, which is defined as a relationship between organizations to achieve goals that cannot be achieved alone, a business can be viewed as a business contract.

Regarding the partnership strategy (T.L Wheelen \& Hunger, 2016) argues that the partnership strategy is an effort to create a competitive advantage from the industry by collaborating with other companies, dividing the partnership strategy into two, namely; collusion and strategy alliance. Cooperative strategies are used by companies to achieve a competitive advantage in the industry by cooperating with other companies. Besides (Hitt et al., 2012) defines a partnership strategy as a strategy between one or more collaborating companies to expand their operations (Douma, 1997). According to (Walker \& Brammer, 2009) the motivation of a company to cooperate is aimed at technology transfer, market access, cost reduction, risk reduction, and industrial structure change. This collaboration is based on trust, openness in sharing risks and enhancing competitive strategies to produce better performance if there is no collaboration (K. Cravens et al., 2000).

The concept of partnership in opinion (D. W. Cravens et al., 2009) is an effort to collaborate with stakeholders, where strategic alliances are used by many competing companies around the world. Partnerships include vertical relationships consisting of relationships with suppliers and customers (customers) as well as horizontal relationships consisting of lateral and internal partnerships. In connection with the concept of customer and supplier relationships conveyed by (Song et al., 2012) states that the focus of business partnerships is customer value creation by highlighting the business relationship function which 
shows 4 functions of supplier-customer partnerships, namely: cost-reduction function, quality function, volume function, safeguarding function.

Business performance is the ability to achieve the goals of a business unit based on certain standards by the objectives (Kaplan, 2005), Business performance is a measure of how effective and efficient a company is in achieving its business goals (Kaplan, 2009), to evaluate business through sustainability, temporal, and spatial (Elkington, 1998). The business performance dimension is based on the achievement of sales goals and profit targets (Gawankar et al., 2015). According to (Martinette et al., 2014) in measuring business performance, it should emphasize the portfolio aspects of its business units, because different organizational characteristics require a certain way of measuring performance.

According to (Wheelen, 2018) performance is the result of activities by including the results of the management process strategy in formulating strategies in achieving company goals, which are factors used to measure the impact of the strategy implemented by the company. Strategic management practice in terms of the ability to improve organizational performance can be measured through indicators of sales volume, market share, and profitability. Company performance is measured by customer satisfaction, financial performance, and market performance (Hosseini \& Sheikhi, 2012); profitability, market share, and cost reduction; and financial performance, customer performance, internal process performance, and growth and learning performance (Karami et al., 2015).

Business performance is the output or result of implementing all activities related to business activities. In this study, business performance is measured by dimensions: sales volume, profitability, and market share, and the partnership strategy in this study is measured by dimensions consisting of internal partnerships, supplier relationships, customer relationships, and lateral partnerships.

\section{METHODS OF RESEARCH}

This research was conducted using an explanatory survey method, the unit of analysis used in the automotive lubricant company in Indonesia, where the unit of observation is the management of the lubricant company. Observations were carried out using a cross-section or one-shot time horizon in 2020. The data source used primary data obtained from a questionnaire through a census to 32 national automotive lubricant companies in Indonesia.

The analysis technique was performed using Structural Equation Modeling (SEM) with Partial Least Squares (PLS) software. According to (Suwarno, 2002), the number of samples of SEM analysis which gives fairly stable results is between 200 to 600 respondents. Meanwhile, according to (Hair et al., 2006;2014) the sample size is $5-10$ times the number of model coefficients to be estimated. SEM analysis with PLS was carried out in three stages, namely outer model analysis, inner model analysis, and hypothesis testing. This study aims to examine the effect of the business environment and company assets on the partnership strategy and its implications for the business performance of automotive lubricant companies in Indonesia. To answer the research objectives, the following hypotheses were formulated:

Research Hypotheses 1: Business Environment Affects Partnership Strategy;

Research Hypotheses 2: Company Asset Affects the Partnership Strategy;

Research Hypotheses 3: Business Environment Affects Business Performance;

Research Hypotheses 4: Company Assets Influence Business Performance;

Research Hypotheses 5: Partnership Strategy Affects Business Performance.

\section{RESULTS OF STUDY}

Evaluation of the value of construct reliability as measured by composite reliability, AVE, and Cronbach's Alpha. Each construct is said to be reliable if it has composite reliability and 
Cronbachs Alpha is greater than 0.70 and AVE is greater than 0.50 (Ghozali, 2011; 2017). The following is an analysis table of the outer research model:

Table 1 - Value (AVE), Composite Reliability and Cronbachs Alpha

\begin{tabular}{|c|c|c|c|}
\hline $\mathrm{n} / \mathrm{n}$ & Cronbach's Alpha & Composite Reliability & Average Variance Extracted (AVE) \\
\hline Business Performance & 0.943 & 0.954 & 0.726 \\
\hline Partnership Strategy & 0.819 & 0.865 & 0.414 \\
\hline Business Environment & 0.855 & 0.888 & 0.461 \\
\hline Company Asset & 0.899 & 0.919 & 0.574 \\
\hline
\end{tabular}

Based on the table above, it can be seen that all constructs have composite reliability greater than 0.70 , so it can be said that the indicators are consistent in measuring the construct. Thus the first-order construct (Business Performance, Partnership Strategy, Business Environment, and Company Asset) has a composite reliability value and a Cronbachs Alpha value above 0.70 . The data shows that the results of all the criteria for the outer model are met so that it can be concluded that the research data has good validity and reliability, therefore it can be continued to the inner model analysis.

Inner model evaluation is indicated by the value of $R^{2}$ (R-Square) in endogenous constructions and $\mathrm{Q}^{2}$ (Predictive Relevance) or known as Stone-Geisser's. $\mathrm{Q}^{2}$ values were obtained 0.02 (minor), 0.15 (moderate), and 0.35 (large), and were only used for endogenous constructs with reflective indicators. Referring to Chin (1998), the $R^{2}$ (R-Square) values are 0.67 (strong), 0.33 (moderate), and 0.19 (weak).

After testing the outer model, the inner model test is carried out as seen from the values: $R^{2}$ (R Square), $Q^{2}$ (Predictive Relevance), GoF (Goodness of Fit). The following are the results of the inner model test:

Table 2 - R-Square Value in Structural Model

\begin{tabular}{|c|c|}
\hline $\mathrm{n} / \mathrm{n}$ & $R$ Square \\
\hline Partnership Strategy & 0.401 \\
\hline Business Performance & 0.551 \\
\hline
\end{tabular}

Based on the R-Square table above, it can be seen that the sub-structure 1 is known that the Partnership Strategy can be explained by the Business Environment and Company Asset at $40.1 \%$ and the remaining $59.9 \%$ is influenced by other constructs not examined in this study. The value of $R^{2}=0.401$ is above 0.33 (criteria for moderate influence, namely $R^{2}>0.33$ ).

Where as in substructure 2, it is known that the Business Performance construct can be explained by the Business Environment, Company Asset, and Partnership Strategy by 55.1\%, and the remaining $44.9 \%$ is influenced by other constructs that are not examined in this study. The value of $R^{2}=0.551$ is above 0.33 (criteria for moderate influence, namely $R^{2}>0.33$ ) so that the total effect of the Business Environment, Company Asset, and Partnership Strategy on Business Performance is in the moderate criteria.

The second step of testing the inner model is $Q^{2}$ testing. The following is the calculation of $\mathrm{Q}^{2}$ which is done manually, namely:

$$
Q^{2}=1-\left[\left(1-R^{2} 1\right)\left(1-R^{2} 2\right)\right]=0,952
$$

From the above calculations, it can be seen that the value of $Q^{2}$ is 0.952 . The $Q^{2}$ value is $0.952\left(Q^{2}>0.35\right)$ which means that the model has been constructed well and has a great predictive ability. 
The third step of testing the inner model is the Goodness of Fit or GoF test. The following are the results of the GoF calculation which is done manually, namely calculating from the root average of AVE $x$ average $R^{2}$ :

$$
\text { GoF }=\sqrt{ } \text { AVE } \times R^{2}=0,509
$$

From the above calculations, it can be seen that the GoF value is 0.509 . The GoF value of 0.509 (GoF> 0.38) indicates that the model formed in this study has a strong structure or strong relationship between variables.

Hypothesis testing on SEM-PLS was carried out by using a bootstrap process which resulted in the t-count value. If the t-value exceeds the t-statistic value with a confidence level of $95 \%$ (> 2.04), then the hypothesis is significant.

Table 3 - Hypothesis Testing

\begin{tabular}{|l|c|c|c|c|l|}
\hline \multicolumn{1}{|c|}{ Hypothesis } & $\gamma$ & $\mathrm{SE}(\gamma)$ & $\mathrm{t}_{\text {-value }}$ & $\mathrm{R}^{2}$ & \multicolumn{1}{c|}{ Conclusion } \\
\hline Business Environment $\rightarrow$ Partnership Strategy & 0,402 & 0,115 & $3,489^{*}$ & 0,230 & Hypothesis accepted \\
\hline Company Asset $\rightarrow$ Partnership Strategy & 0,321 & 0,069 & $4,654^{*}$ & 0,171 & Hypothesis accepted \\
\hline Business Environment $\rightarrow$ Business Performance & 0,188 & 0,087 & $2,159^{*}$ & 0,061 & Hypothesis accepted \\
\hline Company Asset $\rightarrow$ Business Performance & 0,259 & 0,079 & $3,271^{*}$ & 0,093 & Hypothesis accepted \\
\hline Partnership Strategy $\rightarrow$ Business Performance & 0,431 & 0,095 & $4,557^{*}$ & 0,186 & Hypothesis accepted \\
\hline
\end{tabular}

${ }^{*}$ Significant at $\alpha=0.05$ (t-table $=2.04$ ).

\section{DISCUSSION OF RESULTS}

The results of this hypothesis testing illustrate that the automotive lubricant industry business performance is more dominant built by a partnership strategy. Meanwhile, the partnership strategy is more dominantly built by the company's ability to adapt to the business environment than by developing company assets. This illustrates that for the automotive lubricant industry, aspects of the business environment play an important role in encouraging the creation of the right partnership strategy as an effort to achieve expected business performance.

The adaptation of the business environment is dominant in aspects of the macroenvironment which include aspects of economic growth, political, social, technology, and demography, compared to the microenvironment which includes competitors, suppliers, and consumers. Meanwhile, company assets are more dominantly influenced by intangible assets than by tangible assets. Qualifications of employee expertise, employee's ability to collaborate with others, Employee scientific capabilities, and company reputation, are aspects of intangible assets that play a more dominant role than tangible assets in the development of company assets for automotive lubricant companies.

By the research objectives and the tested hypotheses, the results show that: Business Environment affects Partnership Strategy, Company Asset affects Partnership Strategy, Business Environment Affects Business Performance, Company Asset affects Business Performance, and Partnership Strategy affects Business Performance. The partner archive strategy has the highest influence on the business environment. The business environment has the most dominant influence compared to company assets on the partnership strategy.

\section{CONCLUSION}

Based on the results of testing this hypothesis, the automotive lubricant industry business performance is more dominant built by a partnership strategy. And to build the right partnership 
strategy, it needs to be driven by the company's ability to adapt to the business environment and be supported by the ability to develop company assets.

The results of this study have implications for the management of automotive lubricants in Indonesia that efforts to improve business performance need to be pursued through the development of the right partnership strategy, built by efforts to adapt the business environment, especially macro-environmental aspects which include aspects of economic growth, political, social, technology, and demography, and is supported by the ability to develop company assets, especially intangible assets such as Qualifications of employee expertise, employee's ability to collaborate with others, Employee scientific capabilities, and Company reputation.

\section{REFERENCES}

1. Afsharghasemi, A., Zain, M., Sambasivan, M., \& Ng Siew Imm, S. (2013). Market Orientation, Government Regulation, Competitive Advantage and Internationalization of SMEs: A Study in Malaysia. Journal of Business Administration Research.

2. Agboola, J. I., \& Braimoh, A. K. (2009). Strategic partnership for sustainable management of aquatic resources. In Water Resources Management.

3. Ch, R. A., Khattak, J., Khan, M. N., \& Khan, N. A. (2011). Pros \& Cons of Macro Environment (PEST Factors) on New Product Development in Fast Food Industry of Pakistan for Sustainable Competitive Advantage. Interdisciplinary Journal of Contemporary Research In Business.

4. Chuang, H. M., Liu, M. J., \& Chen, Y. S. (2015). The Effects of Human Resource Capability and Internal Customer Satisfaction on Organizational Effectiveness. International Journal of Distributed Sensor Networks.

5. Cravens, D. W., Piercy, N. F., \& Baldauf, A. (2009). Management framework guiding strategic thinking in rapidly changing markets. Journal of Marketing Management.

6. Cravens, K., Piercy, N., \& Cravens, D. (2000). Assessing the Performance of Strategic Alliances: Matching Metrics to Strategies. European Management Journal.

7. Douma, S. (1997). The Two-tier System of Corporate Governance. Long Range Planning.

8. Elkington, J. (1998). Partnerships from cannibals with forks: The triple bottom line of 21stcentury business. Environmental Quality Management.

9. Essmui, H., Berma, M., Shahadan, F. B., Ramlee, S. B., \& Mohd, M. F. Bin. (2014). Structural Equation Model for Analyzing the Impact of Business Environment on Firm's Growth. International Journal of Economics and Finance.

10. Gawankar, S., Kamble, S. S., \& Raut, R. (2015). Performance Measurement using Balance Score Card and its Applications: A Review. Journal of Supply Chain Management Systems.

11. Ghozali, I. (2011). Moderated Structural Equation Modeling. In Model persamaan struktural. Konsep and aplikasi dengan program AMOS 19.0.

12. Ghozali, I. (2017). Model Persamaan Struktural. Konsep and Aplikasi Dengan Program AMOS 24.0. Update Bayesian SEM. In Model Persamaan Struktural. Konsep and Aplikasi Dengan Program AMOS 24. Update Bayesian SEM.

13. Griffin, J. J. (2011). Strategic Management and Business Policy: Toward Global Sustainability, 13th Edition. Journal of Business Ethics Education.

14. Griffin, K. (2003). Economic globalization and institutions of global governance. Development and Change.

15. Hair, J. F., Sarstedt, M., Hopkins, L., \& Kuppelwieser, V. G. (2014). Partial least squares structural equation modeling (PLS-SEM): An emerging tool in business research. In European Business Review.

16. Hair, Money, Samouel, \& Page. (2006). Research Methods for Business. Education and Training.

17. Hibbets, A., Albright, T., \& Funk, W. (2003). The Competitive Environment and Strategy of 
Target Costing Implementers: Evidence from the Field. Journal of Managerial Issues.

18. Hitt, M. A., Ireland, R. D., \& Hoskisson, R. E. (2012). Strategic management cases: competitiveness and globalization. Cengage Learning.

19. Hodud Essmui, B., Berma, M., Bt Shahadan, F., Bt Ramlee, S., Fauzi Bin Mohd, M., Essmui $\alpha$, H., Berma $\sigma$, M., Bt Shahadan $\rho, F$. , \& Bt Ramlee W, S. (2014). The Impact of Business Environment on of Firm's Employment Growth. In journalofbusiness.org.

20. Hoskisson, R. E., Eden, L., Lau, C. M., \& Wright, M. (2000). Strategy in emerging economies. Academy of Management Journal.

21. Hoskisson, R. E., Hitt, M. A., Wan, W. P., \& Yiu, D. (1999). Theory and research in strategic management: Swings of a pendulum. Journal of Management.

22. Hosseini, S. M., \& Sheikhi, N. (2012). An Empirical Examination of Competitive Capability's Contribution toward Firm Performance: Moderating Role of Perceived Environmental Uncertainty. International Business Research.

23. Hunger, D., \& Thomas. L. Wheelen. (2004). Essentials of Strategic Project Management. International Journal of Project Management.

24. Jackson, M. O., \& Wolinsky, A. (1996). A strategic model of social and economic networks. Journal of Economic Theory.

25. John A Pearce, I., \& Richard B Robinson, J. (1988). Strategic management: strategy formulation and implementation. Scrbdcom.

26. Kaplan, R. S. (2005). Strategy \& Leadership How the balanced scorecard complements the McKinsey 7-S model How the balanced scorecard complements the McKinsey 7-S model. Strategy \& Leadership Strategic Outsourcing: An International Journal Iss Management Decision Iss Management Decision.

27. Kaplan, R. S. (2009). Conceptual Foundations of the Balanced Scorecard. In Handbooks of Management Accounting Research.

28. Karami, A., Sahebalzamani, S., \& Sarabi, B. (2015). The Influence of HR Practices on Business Strategy and Firm Performance: The Case of Banking Industry in Iran. IUP Journal of Management Research.

29. Liao, C., Chuang, S. H., \& To, P. L. (2011). How knowledge management mediates the relationship between environment and organizational structure. Journal of Business Research.

30. Makau, M. V., Aa, B., \& Stephen, M. M. (2017). Effect of Working Capital Management on Financial Performance: A Case Study of Listed Manufacturing Firms at Nairobi Securities Exchange, Kenya. International Journal of Management and Commerce Innovations.

31. Martinette, L. A., Obenchain-Leeson, A., Gomez, G., \& Webb, J. (2014). The Relationship Between Learning Orientation And Business Performance: The Moderating Effect Of Sources Of Competitive Advantage. International Business \& Economics Research Journal.

32. Pearce, J., \& Robinson, A. (2011). Strategic management: Formulation, implementation \& control. In Mcgraw Hill Higher Education; 12th Revised edition,2011,.

33. Porter, M. E. (1980). Competitive strategy: Techniques for analyzing industries and competition. New York, 300.

34. Porter, M. E. (1985). Competitive Advantage. In Strategic Management: Vol. May-June (pp. 1-580).

35. Porter, M. E. (2008). The five competitive forces that shape strategy. Harvard Business Review.

36. Robson, P., \& Griffin, K. (2006). Alternative Strategies for Economic Development. The Economic Journal.

37. Sambasivan, M., Loke, S. P., \& Abidin-Mohamed, Z. (2009). Impact of knowledge management in supply chain management: A study in Malaysian manufacturing companies. Knowledge and Process Management.

38. Sambasivan, M., Siew-Phaik, L., Abidin Mohamed, Z., \& Leong, Y. C. (2013). Factors 
influencing strategic alliance outcomes in a manufacturing supply chain: Role of alliance motives, interdependence, asset specificity and relational capital. International Journal of Production Economics.

39. Song, Y., Su, Q., Liu, Q., \& Wang, T. (2012). Impact of business relationship functions on relationship quality and buyer's performance. Managerial Auditing Journal.

40. Suwarno, S. and. (2002). Model Persamaan Structural, Teori and Aplikasinya. IPB Press.

41. Teece, D. J. (2010). Business models, business strategy and innovation. Long Range Planning.

42. Teece, D. J. (2012). Dynamic Capabilities: Routines versus Entrepreneurial Action. In Journal of Management Studies.

43. Todeva, E., \& Knoke, D. (2005). Strategic alliances and models of collaboration. In Management Decision.

44. Uddin, M., \& Akhter, B. (2011). Strategic Alliance and Competitiveness: Theoretical Framework. Journal of Arts Science \& Commerce ISSN.

45. Walker, H., \& Brammer, S. (2009). Sustainable procurement in the United Kingdom public sector. Supply Chain Management.

46. Wheelen, et. al. (2018). Concepts In Strategic Management \& Business Policy. Globalization, Innovation and Sustainability. Fifteenth Edition. In Global Edition. Pearson Education Limited. United Kingdom.

47. Wheelen, T. L., \& Hunger, J. D. (2010). Basic concepts of strategic management. Concepts in Strategic Management and Business Policy.

48. Wheelen, T.L, \& Hunger, J. . (2016). Strategic Management and Business Policy Toward Global Sustainability. In Journal of Mathematical Sciences (United States).

49. Wheelen, Thomas L, \& David Hunger, J. (2012). Strategic Management and Business Policy Toward Global Sustainability Thirteenth Edition. Strategic Management and Business Policy Toward Global Sustainability.

50. Wu, S. I., \& Lu, C. L. (2012). The relationship between CRM, RM, and business performance: A study of the hotel industry in Taiwan. International Journal of Hospitality Management. 